\title{
GENOTOXIC AND HISTOPATHOLOGICAL EFFECTS OF CHLORPYRIFOS ON AFRICAN CATFISH, $C$. gariepinus AND AMELIORATIVE POTENTIALS OF ACKEE APPLE, Blighia sapida SEED
}

\author{
Iyiola, O. A A,* $^{\mathrm{a}, \text { Adeagbo, A.A }}$, Weliange, W. S $^{\mathrm{b}}$, Sulaimon, F. A ${ }^{\mathrm{c}}$, Abdulkareem, S.I ${ }^{\mathrm{b}}$ Abass, T. Anifowoshe ${ }^{\mathrm{a}}$ and Belewu M.A ${ }^{\mathrm{d}}$ \\ ${ }^{a}$ Dept. of Zoology, Cell Biology and Genetics Unit, University of Ilorin, P.M.B 1515, Ilorin Kwara state, Nigeria - (iyiola.oa@ unilorin.edu.ng) \\ ${ }^{b}$ Dept. of Zoology, Fisheries and Hydrobiology Unit, University of Ilorin, P.M.B 1515, Ilorin, Kwara state, Nigeria. \\ ${ }^{c}$ Dept. of Biochemistry, University of Ilorin, P.M.B 1515, Ilorin, Kwara state, Nigeria. \\ ${ }^{d}$ Dept. of Animal Production, Microbial Biotechnology and Dairy Science Laboratory, University of Ilorin, Nigeria.
}

Received: Jan. 2018 / Accepted: Mar., 2018 / Published: Mar., 2018

https://doi.org/10.25271/2018.6.1.422

\begin{abstract}
:
Chlorpyrifos (CPF) is a very toxic pesticide commonly used for controlling agriculturally important pests. The present study investigates DNA damaging effects of CPF on Clarias gariepinus was assessed using genetic assays. Fish were exposed to varying concentrations of CPF (100ppm, 200ppm and 300ppm) at 96 hours (acute exposure). LC 50 of the pesticide was found to be 120ppm and one-tenth of the $\mathrm{LC}_{50}(12 \mathrm{ppm})$ was taken for the chronic exposure. Distilled water and colchicine were used as negative and positive controls respectively. After 28 days of chronic exposure, fish were fed with inclusion of $B$. sapida seed (powder) for 14 days. Liver and gills of the fish were removed following $96 \mathrm{~h}$ exposure, days 7, 14 and 28 of the chronic exposure as well as after the period of amelioration (14 days) for CA assay and histopathological analysis. The results of CA assay showed statistically significant $(p<0.05)$ increase in CA in a dose-dependent manner for all the exposed groups after acute exposure and time dependent after chronic exposure. Also, this study showed that CPF can potentially induce genotoxic and histopathological changes in fish and other aquatic organisms.
\end{abstract}

KEYWORDS: DNA Damage; Chromosome Aberrations; Acute; Chlorpyrifos; Genotoxic.

\section{INTRODUCTION}

Pesticide is one of the aquatic pollutants that contribute to the environmental problems all over the world. This is due to increase in the use of pesticides as a means of controlling insect pests in agricultural farmlands (Abowei and Sikoki, 2005; Osman et al., 2011). A significantly large amount of the applied pesticides end up in aquatic environments (e.g. rivers, lakes and ponds) as reported by Werimo et al. (2009) and Esminger et al (2011). Contamination of aquatic water bodies by pesticides have been reported to have adverse effects on the growth and survival in aquatic animals (Candioti et al., 2001; Bolognesi, 2003; Cavas and Ergene-Gozukara, 2005; Mohanty et al., 2011). Piemental and Leviton (1986) showed that less than $1 \%$ of the pesticides used reach the target organism. The implication of this is that more than $99 \%$ that remain are left within the ecosystem, with the help of rainfall, a large portion of this left-over are washed to the nearby water body (Vocke, 1986; Hellar, 2002; Ambali et al., 2010). Considering the report of EPA (2001), several conventional pesticides are used in different areas all over the world on annual basis. This shows that pesticides are spread across the ecosystem worldwide on a yearly basis if the estimate of Piemental and Leviton (1986) is put into consideration. Arjmandi et al. (2010) reported that the remaining insecticides that did not reach the target organism are very toxic to non-target organisms in the natural environments that are close to the point of application. Fish are very sensitive organism to the environmental contaminants and as such, pollutants such as pesticides may initiate a significant disruption of certain metabolic activities in fish as a result of contact between the contaminants and fish organs (John, 2007). Many studies that were conducted in recent times have shown that pesticides can impair the health of fish (Siang et al., 2007;
Nwani et al., 2010a). Since fishes are important sources of proteins and lipids for humans, the health of fish is very important to humans that depend on them. More importantly, reports of previous studies revealed the genotoxic and cytotoxic potentials of pesticides on different species of fish (Al-Sabti and Metcalfe, 1995; Hartwell et al., 2000; Ali et al., 2008; Nwani et al., 2010b). health of fish (Siang et al., 2007; Nwani et al.,2010b). Since fishes are important sources of proteins and lipids for humans, the health of fish is very important to humans that depend on them. More importantly, reports of previous studies revealed the genotoxic and cytotoxic potentials of pesticides on different species of fish (Al-Sabti and Metcalfe, 1995; Hartwell et al., 2000; Ali et al., 2008; Nwani et al., 2010a).

Chlorpyrifos (CPF), (O,O,-diethyl-O-3,5,6-trichloro-2-pyridyl phosphorothioate) is an organophosphate pesticide used for controlling insect pests of agricultural importance such as cutworms, corn rootworms etc (Rao et al., 2003). It is also used as insecticides for indoor use in the control of domestic insects such as mosquitoes, cockroaches and houseflies (Daoud et al., 2009). CPF is a very toxic pesticide and increase in its load in aquatic environment can put the existence of non-target fish at risk (Rao, 2008). CPF is a can inhibits the acetyl cholinesterase (AChE) in synaptic junctions of the nervous system (Rames and Muniswamy 2009; Banae et a.., 2011) which can lead to disruption of the nervous system and ultimately death in animals (Timchalk, 2010; Nwani et al. ,2013a; Nwani et al.,2013b). Genotoxic properties of CPF have also been observed in the previous studies using different assays (although with varying results). The residual effects of CPF could be very harmful to aquatic animals even at low exposure (Humphrey et al. 2004). The primary mode of action of organophosphate pesticides has been established in mammals (Testai et al., 2010) and in aquatic organisms, particularly the

\footnotetext{
${ }^{*}$ Corresponding Author

This is an open access under a CC BY-NC-SA 4.0 license (https://creativecommons.org/licenses/by-nc-sa/4.0/)
} 
fish (Giesy et al., 1999). Reports from previous studies have clearly shown that $\mathrm{CPF}$ is genotoxic to non-target animals including fish because of its ability to inhibit DNA synthesis as reported by Whitney et al. (1995). Rahman et al. (2002) and Daoud et al. (2009) observed that CPF is genotoxic to Channa punctatus using micronucleus and comet assays. However, no previously published report on genotoxic effect of CPF on $C$. gariepinus using chromosomal aberration assay. Blighia sapida (Ackee apple) is a plant that belongs to the Sapindaceae (soapberry family) and its botanical name was derived from Captain William Bligh who brought it to London in the $18^{\text {th }}$ century (Veronica et al., 2014). Alkaloids, saponins, flavonoids, tannins and phenols are the common bioactive contents of B. sapida seed. Phenols and flavonoids are more available in the ripe ackee seeds while alkaloids and saponins are higher in the unripe ackee seeds (Emmanuel et al., 2014). Hence, using ripe ackee seed as an inclusion in animal feed is more suitable than unripe seed. The major antioxidants in ackee apple seed are phenol and flavonoids. Flavonoids are antioxidants with anti-inflammatory activity (Okwu, 2005). The large amounts of flavonoids in B. sapida is an indication that the ackee seed can offer certain biochemical functions such as protection against allergies, inflammation, free radical etc (Okwu, 2004; Ekué et al., 2010). Flavonoids are water soluble antioxidants and free radical scavengers which can as well prevent oxidative cell damage $(\mathrm{Okwu}, 2004)$ which is one of the mechanisms of toxic chemicals. Flavonoids also have anticancer potential and protect against the different levels of carcinogenesis (Emmanuel et al., 2014). Despite the antioxidant properties of $B$. sapida seed, there is no documented evidence on its usage as ameliorative agent. Therefore, this study investigated genotoxic and cytotoxic effects of CPF on African catfish, Clarias gariepinus using chromosomal aberration and histopathological assays. In addition, possible ameliorative effect of $B$. sapida was also studied.

\section{MATERIALS AND METHODS}

\subsection{Test Chemical (Pesticide)}

Chlorpyrifos (20\% EC) manufactured by M/s. K \& N Efthymiadis, Greece was procured from the local market of Ilorin, Nigeria, under the trade name of Jubaili. It was confirmed that the chlorpyrifos of this grade is mostly employed in the fields.

\subsection{Water Quality Parameters}

The water quality such as temperature, $\mathrm{pH}$, dissolved oxygen and conductivity were monitored throughout the period of the experiment

\subsection{Ethical Approval}

Ethical clearance was obtained from the University Ethical Review Committee (UERC) of University of Ilorin, Ilorin, Nigeria. The UERC approval number is UERC/ASN/2016/416.

\subsection{Experimental Animal}

Healthy juvenile African catfish, (Clarias gariepenus) were bought from Kwara State Fish Farm in Ilorin. The average wet weight and length of the fish were $38.56 \pm 2.0 \mathrm{~g}$ and $20.20 \pm 3.0 \mathrm{~cm}$ respectively. The fish were acclimatized in well aerated water for two weeks during which they were fed $5 \%$ of their body weight with commercial fish feed (Skreting ${ }^{\circledR}$ Fish Feed) in the morning and evening. The quality of the water was put at optimum by siphoning and changing the water every 48 hours to prevent feeds and faecal matter from contaminating the water with the aim of providing a healthy environment for the fish. Carcass from all the sacrificed fishes were buried immediately after removing all the organs needed from them for analysis.

\subsection{Collection and Preparation of B. sapida Seed}

Ripe B. sapida (Ackee apple) seed was collected in Ilorin metropolis. The seeds were then extracted from the matured fruits. The seeds of $B$. sapida were prepared using biochemical method. The seeds of $B$. sapida were sun-dried for a month after which they were milled using attrition mill. The milled $B$. sapida seed was soaked in petroleum ether and allowed to stay for 16 hours. The B. sapida seed oil which is less dense than the solvent (petroleum ether) was decanted and the residue solvent in the ackee seed was evaporated. The defatted ackee seed cake was packed in polythene bags and autoclaved at $121^{\circ} \mathrm{C}$ and 15 psi for 15 minutes to remove any microorganism which could be present in the cake and allowed to cool. Aspergillus niger was introduced into the seed cake incubated at room temperature. In 7 days, the fungus (Aspergilus niger) have colonized the substrate and the growth was terminated by oven drying the cake at $70^{\circ} \mathrm{C}$ for 24 hours.

\subsection{Acute and Chronic Toxicity Bioassay}

Following the preliminary range finding test, 10 pieces of juvenile African catfish, C. gariepinus were introduced into each container of $20 \mathrm{~L}$ of water containing $100 \mathrm{ppm}, 200 \mathrm{ppm}$, $300 \mathrm{ppm}, 400 \mathrm{ppm}$ of CPF (20\% EC) for a period of $96 \mathrm{hr}$ (Acute test). A control experiment was also set up in distilled water at the same time. Each of the group was set up in triplicate. The experiment was carried out using a static non-renewal bioassay for a period of 96 hours. The fish were not fed throughout the 96h exposure and the water media was replaced daily to ensure consistent concentration. Mortality, morphology and general behaviour of the fish were also noted after 96 hours.

The lethal concentration at $50 \%$ mortality was calculated using Arithmetic Method of Karber for calculating $\mathrm{LC}_{50}$ adopted by Dede (1992):

$L C_{50}=L C_{100}-\sum$ (Mean Death $x$ Conc. Diff) $\div$ No of Fish per Group

A total of 8 plastic containers were used for definitive toxicity bioassay. Ten juveniles of $C$. gariepinus were introduced into three containers with $20 \mathrm{~L}$ of water containing the same concentration (12ppm of CPF) i.e. one tenth of the $\mathrm{LC}_{50}$ in duplicate. A control experiment containing distilled water was also set up in duplicate. The water media were replaced every 48 hours to allow for consistency in the CPF concentration of the media.

\subsection{Amelioration Procedure}

The three groups of fish exposed to CPF were fed with feed formulated with $B$. sapida during the period of amelioration which lasted for 14 days. The first group of the treated fish were fed with feed containing $25 \%$ inclusion level of B. sapida while the second and third groups were fed with the feed containing $50 \%$ and $75 \%$ inclusion level of B. sapida respectively. Fish in the control group were however fed with normal feed i.e. $0 \%$ inclusion level of $B$. sapida.

\subsection{Collection of Samples for histological investigation (Liver and Gill)}

Feeding was suspended for 24 hours prior to the time of collection of liver and gill sample for CA assay and histopathological analysis after acute toxicity test, chronic exposure and amelioration period. This was necessary in order to reduce stress like gastrointestinal disturbance (in the animal) during the process of sacrifice (Garcia and Martinez, 2012). 


\subsection{Chromosomal Aberration Assay}

The chromosomal aberration assay of $C$. gariepinus exposed to various concentrations of $\mathrm{CPF}$ and ameliorated with $B$. sapida in this study was carried out using the procedures followed by Nagpure and Barat (1997) and Asano et al. (1998) with little modifications. Fishes were dissected to remove livers from the fish in the control groups (positive and negative) as well as the treated groups following acute and chronic exposure and amelioration. The livers were put in different petri-dishes and then homogenized in freshly prepared $0.56 \%$ of $\mathrm{KCl}$ using mortar and pestle. The cell suspension was poured into $15 \mathrm{ml}$ centrifuge tube and incubated for 25 minutes at room temperature. The hypotonic action of the $\mathrm{KCl}$ was stopped by adding $1 \mathrm{ml}$ of freshly prepared and chilled Cannoy's fixative (methanol and acetic acid at 3:1) and left for 30 minutes. Then, the cell suspension was centrifuged at $1500 \mathrm{rpm}$ for 10 minutes at room temperature. Supernatant was removed with a micropipette and cell pellet was slowly over layer 6-8 ml freshly prepared chilled Cannoy's fixative. Thereafter, the cell suspensions were centrifuged at $1500 \mathrm{rpm}$ for 10 minutes at room temperature. Supernatant was removed leaving behind the cell pellet at the bottom of the tube. This was then followed by adding another fresh and chilled Cannoy's fixative. This step was repeated 3 times until transparent cell suspension was obtained and the clear cell suspension was spread onto grease free and clean slide using a micropipette. The slides were allowed to air dry overnight ( 24 hours). The slides were then stained with freshly prepared $10 \%$ may-grunwald stain and then rinsed in distilled water. After air-dried, the slides were finally stained with 5\% Giemsa stain for 10 minutes and the metaphase spread was then viewed under (OLYMPUS microscope) at oil immersion objective 100X. The microphotographs of the slides were then taken using Amscope digital camera 3.1MP APTINA Colour CMOS fastened to the ocular eye piece of the microscope. Mitotic index (MI) \pm S.E. was calculated for all the experimental groups.

\section{HISTOPATHOLOGICAL ANALYSIS}

The fishes were dissected to remove the gills for histopathology assay in order to assess the level of damage on the tissues and cells of the exposed fishes. The removed gills were fixed in $10 \%$ formalin (Sheehan and Hrapchak, 1980) to maintain its freshness and taken to Pathology Unit, University of Ilorin Teaching Hospital for histopathological analysis.

\subsection{Statistical Analysis}

The results obtained from this study were expressed as mean \pm standard error (SE) for chromosomal aberration tests. To assess the significance of the differences at each sampling time, statistical analysis was performed using one-way analysis of variance (ANOVA) for CA results. Any $P$ value that is less than 0.05 was taken as statistically significant using SPSS 16.0 version.

\section{RESULTS}

\subsection{Chromosomal Aberrations}

Various kinds of chromosomal aberrations were observed in the structure of the chromosome of the specimen after acute exposure, chronic exposure and amelioration period. The CAs observed in the treated group includes; centromeric gap, acentric fragment, chromatid breaks, chromatid gaps, centromeric breaks, chromatid gap. No CA was observed in the liver cell of fish in the negative control group. As expected fish in the positive control group showed the highest number of chromosomal aberrations. The most frequent type of chromosomal aberrations observed in this study was chromatid break followed by centromeric gaps, acentric fragment and chromatid gap. Also, the frequency of chromosomal aberrations observed in this study was concentration and time dependent in both acute and chronic exposure. Increase in frequency of chromosomal aberrations was observed to be low following acute exposure such that at $100 \mathrm{ppm}$ concentration, the chromosomal aberrations frequency observed was 70 chromosomal aberrations out of 1000 which were found to be higher i.e. 159 chromosomal aberrations at $300 \mathrm{ppm}$ concentration (Table 1). Also, the frequency of chromosomal aberrations during chronic exposure increased from 92 chromosomal aberrations after the $7^{\text {th }}$ day to 225 chromosomal aberrations after the $28^{\text {th }}$ day of exposure. However, the frequency of damage tends to become reduced after amelioration. The group fed with 50\% Blighia sapida seed inclusion showed the lowest frequency of chromosomal aberrations (14) followed by the group fed with $25 \%$ Blighia sapida seed inclusion level with a frequency of 28 chromosomal aberrations but the group fed with $75 \%$ Blighia sapida seed inclusion level showed a frequency of (49) chromosomal aberrations

Table 1. Frequency of Chromosomal Aberrations Induced by Chlorpyrifos in Liver cells of C. gariepinus after Acute Exposure

\begin{tabular}{ccccc}
\hline Concentration & Total CA & Mean CA \pm SE & $\%$ CA & MI \pm SE \\
\hline NC (0.0) & 0 & $0 \pm 0$ & 0 & $36.7 \pm 0$ \\
$100 \mathrm{ppm}$ & 70 & $23.3 \pm 0.9^{*}$ & $2.9^{*}$ & $26.7 \pm 0$ \\
$200 \mathrm{ppm}$ & 130 & $43.3 \pm 1.2^{*}$ & $6.2^{*}$ & $23.3 \pm 0$ \\
$300 \mathrm{ppm}$ & 159 & $53.0 \pm 2.5^{*}$ & $9.6^{*}$ & $18.3 \pm 0$ \\
PC (Colchicine) & 192 & $64.0 \pm 2.7^{*}$ & $32.0^{*}$ & $6.7 \pm 0$
\end{tabular}

Values with* differ significantly from the control $(P<0.05)$ $\mathrm{NC}=$ Negative control, $\mathrm{PC}=$ Positive control, $\mathrm{CA}=$ chromosomal aberration, $\mathrm{SE}=$ Standard error, $\mathrm{MI}=$ Mitotic index

Table 2. Frequency of Chromosomal Aberrations Induced by Chlorpyrifos to Liver cells of C. gariepinus after Chronic Exposure

\begin{tabular}{cccccc}
\multicolumn{7}{c}{ and Amelioration } \\
\hline Concentration & $\begin{array}{c}\text { Time } \\
\text { (day) }\end{array}$ & $\begin{array}{c}\text { Total } \\
\text { CA }\end{array}$ & $\begin{array}{c}\text { Mean } \\
\text { CA } \pm \text { SE }\end{array}$ & $\begin{array}{c}\% \\
\text { CA }\end{array}$ & MI \pm SE \\
\hline NC (0.0) & - & 0 & 0 & 0 & $40.0 \pm 1.0$ \\
$12 \mathrm{ppm}$ & 7 & 92 & $30.7 \pm 1.2^{*}$ & $4.64^{*}$ & $22.0 \pm 0.5$ \\
$12 \mathrm{ppm}$ & 14 & 130 & $43.3 \pm 1.2^{*}$ & $8.7^{*}$ & $16.7 \pm 0.1$ \\
$12 \mathrm{ppm}$ & 28 & 225 & $75.0 \pm 1.2^{*}$ & $37.5^{*}$ & $6.7 \pm 0.3$ \\
$\begin{array}{c}\text { B.sapida } \\
(25 \%)\end{array}$ & 14 & 28 & $9.30 \pm 1.2^{*}$ & $1.6^{*}$ & $20.0 \pm 0.1$ \\
$\begin{array}{c}\text { B.sapida } \\
(50 \%)\end{array}$ & 14 & 14 & $4.70 \pm 0.3^{*}$ & $2.3^{*}$ & $19.5 \pm 0.2$ \\
$\begin{array}{c}\text { B.sapida } \\
(75 \%)\end{array}$ & 14 & 49 & $16.30 \pm 0.3^{*}$ & $8.2^{*}$ & $18.5 \pm 0.1$ \\
$\begin{array}{c}\text { PC } \\
\text { Colchicine) }\end{array}$ & - & 255 & $85.0 \pm 1.2^{*}$ & $42.5^{*}$ & $6.7 \pm 0.0$ \\
\hline
\end{tabular}

Values with* differ significantly from the control $(P<0.05)$ $\mathrm{NC}=$ Negative control, $\mathrm{PC}=$ Positive control, $\mathrm{CA}=$ chromosomal aberration, $\mathrm{SE}=$ Standard error, $\mathrm{MI}=$ Mitotic index

\subsection{Histopathological Analysis}

No recognizable changes were observed in the gills of the negative control group (Figure 1). At different concentrations of CPF, there were observable pathological changes in the gills of $C$. gariepinus after acute and chronic exposure to varying concentration of CPF. Exposure of the fish to CPF after acute and chronic period showed similar pathologies but severity of 
the pathologies differs. However, the level of the damage or injuries was observed to be less severe after amelioration. The major histopathological changes observed include lamellae necrosis (in both primary and secondary lamellae) which ranges from mild to severe. Also, detachment of primary lamella epithelia was observed after exposing the fish to CPF. Other observable pathological conditions of the gill include: hyperplaxia, edema and dilation of the lamellae (Figure 2, 3, 4 and 5) as compared with Fig. 1(normal)

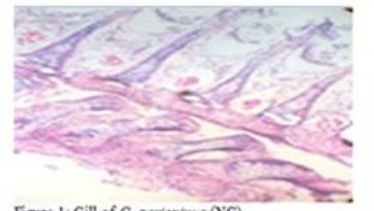

Figure 1: Gill of $C$ gariepinut (NC)

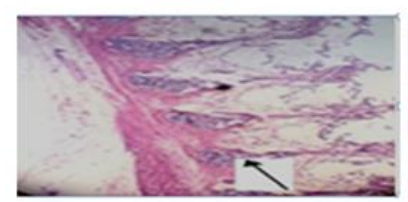

Figure 3: Gill of $C$ garieptmus exposed to $100 \mathrm{ppm}$ chlorpyrifos.

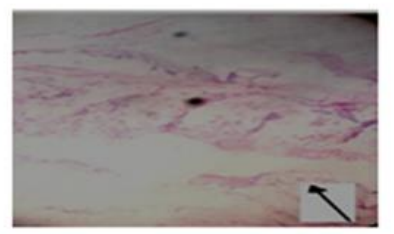

Figure 5: Gill of C gariegonus after amelioration.
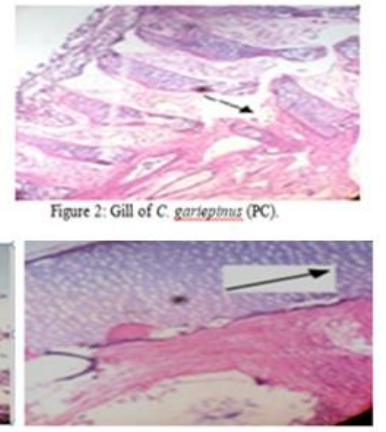

Figure 4: Gill of $C$. garieponus exposed to $300 \mathrm{ppm}$ chlorpyrifos.

\section{DISCUSSION}

Fish are capable of metabolizing and storing aquatic pollutants (Daoud et al., 2009) upon exposure to aquatic pollutants. The lipophilic nature of toxicants like pesticides makes their accumulation within the tissue of exposed fish possible thereby resulting into impairment in the biology of fish. The aim of this study is to evaluate the genotoxicity of CPF in African catfish, C. gariepinus because of its suitability as animal model for studying aquatic pollutants. Also, C. gariepinus was selected for this study because of the flexibility in its culturing as it can withstand stress for a long period of time and its faster growth rate. Secondly, C. gariepinus is of great economic importance to the Nigerian fishery at the local level either in the wild or aquaculture being one of the commonest species in the wild and at the same time, the dominant fish species in Nigerian aquaculture.

Various types of behavioural displays such as loss of balance, irregular movement and restlessness were observed by the treated fish during acute exposure in this study and this could be due to the fact that pesticides can alter the behaviour of fish by interrupting the mechanisms or physiological routes of nervous system (Pan and Dutta, 1998). The unusual behavioural responses of $C$. gariepinus in this study could be connected to primary effect of organophosphate pesticide which is the inhibition of acetylcholinesterase enzyme (AChE). Acetylcholinesterase enzyme (AChE) is one of the enzymes that can inactivate acetycholine (Futlon and Key, 2001) which is capable of disrupting the path of neurotransmitter. According to Sunanda et al. (2016), chlorpyrifos induced alterations in histopathology of various fish species are extensively studied. Thus, the behavioural displayed and various lesions observed in the gill of the treated fish maybe as a result of the chemical constituent of the pesticide. The observations in this study is similar to the work of Topal et al (2014); Devi and Mishra (2013); and De Silva and Samayawardhena (2002). Therefore, a long-term exposure of fish to chloripyfos is capable of causing respiratory dysfunction. The use of fish as bioindicator for assessing the genotoxic property of aquatic pollutants such as pesticides (Rishi and Grewal, 1995; Kamal and Renu, 2010; Yadira et al., 2015) and heavy metals (Yadav and Trivedi, 2009) using chromosomal aberration assay has been proven to be successful and useful by the previous studies.

Chromosomal aberration (CA) represents a small fraction of the alteration or deformation in the structure of chromosomal DNA (Caporale, 1999). Chromosomal aberrations (CA) are among the important biological consequences of exposure of living organisms to genotoxic agents (Bryant, 1998). Different types of cancers have been found to have connection with certain types of chromosomal aberrations in human being (Mitelman et al., 1997) but in animals like fish, chromosomal aberrations is regarded as indicator of genotoxic substance. Chromosomal aberrations are induced by agents that cause damage to chromosomal DNA. Previous experimental analyses have shown that strand breaks are the principal lesions in the process of chromosomal aberrations formation (Bryant, 1998). The results of chromosomal aberration assay as observed in this study showed that the liver cells of all the treated groups after acute and chronic period showed statistically significant $(P<0.05)$ increase in the mean chromosomal aberration when compared with the negative control group. Similarly, chromosomal aberrations observed in this study increases with an increase in the concentration of CPF relative to the negative control group where no chromosomal aberration was observed (Table 1 and 2). The significant decrease in mitotic index $(P<$ 0.05 ) in the treated fish compare to the fish in negative control group as observed in this study which decreases with increase in concentration and time of exposure may be as a result of CPF toxicity that hinder cell division (mitosis). The disruptions of mitotic cell division might have led to the formation of different chromosomal aberrations that were observed in the groups treated with varying concentrations of $\mathrm{CPF}$. The different types of chromosomal aberrations that were observed in $C$. gariepinus in this study are similar to observation of previous studies after exposing Channa punctatus to different kinds of pesticides and other toxicants. Yadav and Trivedi (2009) observed chromatid break and chromosomal break in Channa punctatus after 168 hour ( $7^{\text {th }}$ day) exposure to three different heavy metals. Centromeric gap and acentric fragment were also among the chromosomal aberrations that were reported by Rishi and Grewal (1995) in Channa punctatus treated with dichlorvos for 96 hours. Conversely, some reports on fish chromosomal aberration assay slightly differ from results of this study in terms of increase in the frequency of chromosomal aberration with respect to increase in the time or duration of the exposure. Their results did not indicate a progressive increase in the frequency of chromosomal aberrations induced by toxicants after exposure. For instance, Rishi and Grewal (1995) observed a decrease in the total chromosomal aberration in Channa punctatus treated with dichlorvos. They observed that the frequency of chromosomal aberrations observed after $24 \mathrm{hr}$ exposure reduced from 45 to 9 after $96 \mathrm{hr}$ exposure. Also, Kamal and Renu (2010) observed a higher frequency of chromosomal aberration in the kidney cell of Channa punctatus after exposure to fenvalerate pesticide at the onset of the experiment which later declined towards the end of the period of exposure in the treated groups. Although, Bremmer et al. (1988) reported that pesticide like dichlorvos was not genotoxic to man but the report of Rishi (1989), Rishi and Haobam (1990), Biswas and Manna (1992), Rishi and Sunita (1993), Rishi and Grewal (1995), and Kamal and Renu (2010) clearly established that pesticides is genotoxic to fish because of observable chromosomal aberrations that were recorded following either acute or chronic exposure of different species of fish to varieties of pesticides. Moreover, the result of this study showed a significant decrease in the chromosomal aberration recorded after the period of amelioration with 
Blighia sapida inclusion after two weeks (14days). The reduction in the frequency of chromosomal aberrations was optimum in the group ameliorated with 50\% Blighia sapida inclusion level (from $75 \pm 1.2$ to $4.7 \pm 0.3$ as presented in Table 2 ) and this may be suggestive of the best inclusion level (50\%) for ameliorative purpose in the fish exposed to CPF. However, the increase in chromosomal aberrations in the groups that were fed with $75 \%$ Blighia sapida inclusion level may be due to the fact that the $75 \%$ inclusion level is more than the tolerable limit for the fish and thus becomes toxic to the animal.

Histopathological examination is a sensitive procedure for assessing cellular impairment in the organ of an animal following their expose to xenobiotics (Ayoola and Ajani, 2008). Fish exposed to pollutants have been reported to display various pathological conditions in different organs such as liver, kidney and gill after their exposure to toxicants (Ahmadivand et al., 2014). The gill of fish is capable of absorbing toxicants with the gill filaments and lamellae being the most important site of the action of xenobiotics in the gill. This implies that fish gill is a good indicator of water quality. Fish gills are prone to toxicity of aquatic pollutants in water because of their relatively large surface area and their location (Elif and Erhan, 2006). The lesions observed in the gill of $C$. gariepinus treated with $\mathrm{CPF}$ may be an indication of cytotoxicity of CPF that was suspected in the liver cells of the treated fish as revealed by the chromosomal aberration in this study. Also, the necrosis observed in the gill as observed is a form of traumatic cell death that occur as a result of acute cellular injury. This might be probably due to disruption of mitotic cell division that was caused by CPF concentration in the exposed fish. The pathological changes observed in this study corroborate the observation of Elif and Erhan (2006). Also, lesions observed in the gill tissues of C. gariepinus exposed to CPF in this study are similar to pathological distortions that were observed in the gills of Oreochromis niloticus following its exposure to dimethoate (Elezaby et al., 2001) and $C$. gariepinus exposed to fenthion at varying concentrations (Somdare et al., 2015). Vidhya and Radhakrishnan (2013) reported lamellae necrosis and edema in the gill of Etroplus suratensis exposed to Lambda-cyhalothrin pesticide and this is in agreement with the histopathological changes in the gill of specimen that was used for this study. However, the necrosis observed in this study was later observed to be mild after the period of amelioration. Although, Myers et al. (1992) stated that gill has the ability to recover from the damage suffered during exposure to water pollutants if the environmental condition becomes normalized.

\section{CONCLUSION}

CPF is a popular pesticide all over the world but little attention is paid to the detrimental and genotoxic effects that it has on the living organisms in the environment especially the aquatic ecosystem which is usually the ultimate recipient. Based on our findings, we therefore suggest that the use of CPF and other pesticides has to be properly monitored in order to reduce their possible genotoxic effects on fish and other aquatic organisms. Also, the use of Blighia sapida in this study to ameliorate cytotoxic and genotoxic effects of the effluents on fish may results into commercialization of the plant for large scale use in bioremediation.

\section{CONFLICT OF INTEREST}

The authors declare no conflict of interest.

\section{ACKNOWLEDGEMENT}

We wish to thank the authority of the Department of Zoology, University of Ilorin, Nigeria for making available the facilities used for this study.

\section{REFERENCES}

Abowei, J.F.N. and Sikoki F.D. (2005).Water Pollution Management and Control. Double Trust Publications, PortHarcourt, ISBN: 978303802016, pp 236.

Ahmadivand S., Farahmand, H., Mirvaghefi, A.R., Eagderi,S., Shokrpoor, S., and Rahmati-Holasoo, H. (2014): Histopathological and Haematological Response of Male Rainbow Trout (Oncorhynchus mykiss) Subjected to Butachlor. Veterinarni Medicina, 59 (9): 433-439.

Ali, D., Nagpure, N.S., Kumar, S., Kumar, R., Kushwaha, B., and Lakra, W.S. (2009). Assessment of Genotoxic and Mutagenic Effects of Chlorpyrifos in Freshwater Fish Channa punctatus (Bloch) Using Micronucleus Assay and Alkaline Single-Cell gel Electrophoresis. Food Chemistry and Toxicology, 47(3):650-656.

Al-Sabti, K. and Metcalfe, C.D. (1995). Fish Micronuclei for Assessing Genotoxicity in Water: sensitive Monitor for Aquatic Pollution, African Journal of Mutation Research, 343: 121135.

Ambali, S.F., Abubakar, A.T., Shittu, M., Yaqub L.S., Anafi, S.B. and Abdullahi, A. (2010). Chlorpyrifos induced alteration of hematological parameters in wistar rats: ameliorative effect of zinc. Research Journal of Environmental Toxicology, 4(2):55-66.

Arjmandi, R., Tavakol, M. and Shayeghi, M. (2010). Determination of organophosphorus insecticide residues in the rice paddies. International Journal of Environmental Science Technology, 7 (1): 175-182.

Asano, Y.F.N., Sifuni, T. and Ojima, Y. (1998). Development of genotoxic assay in systems that use aquatic organisms. Mutation Research, 399: 125-133.

Ayoola, S.O. and Ajani E.K. (2008). Histopathological effects of cypermethrin on juvenile african catfish (Clarias gariepinus). World Journal of biological research 001: 2.

Banaee, M., Sureda, A. Mirvaghefi, A.R. and Ahmadi, K. (2011). Effects of Diazinon on Biochemical Parameters of Blood in Rainbow Trout (Onchorhynchos mykiss). Pesticide Biochemistry and Physiology, 99:1-6.

Biswas, S. and Manna, G.K. (1992). The 'Hay Bacillus', Bacillus subtillis as Genotoxic Agent in Treated Fresh Water Tilapia, In: Perspectives of Cytology and Genetics Manna G.K. and Roy, S.C. (Ed) 7, pp 945-952.

Bolognesi, C. (2003). Genotoxicity of Pesticides: A Review of Human Biomonitoring Studies. Mutation Research, vol. 543, pp. 251-272.

Bremmer, J.N., Walker, A.I.T. and Grasso, P. (1988). Is Dichlorvos a Carcinogenic Risk for Humans? Mutation Research, 209: 35-44.

Bryant, P. E. (1998).The signal model: a possible explanation for the conversion of DNA double-strand breaks into chromatid breaks. International Journal of Radiation Biology, 73: 243-251.

Candioti, J.V., Soloneski, S., and Larramendy, M.L. (2010). Genotoxic and Cytotoxic Effects of the Formulated Insecticide Aficida on Cnesterodon decemmaculatus (Jenyns, 1842) (Pisces: Poeciliidae). Mutation Research, 703, 180-186.

Caporale L.H. (Ed.), (1999). Molecular Strategies in Biological Evolution. Annal of New York Academic of Science. 870.

Çavas, T., Garanko, N.N. and Arkhipchuk, V.V. (2005). Induction of Micronuclei and Binuclei in Blood, Gill and Liver cells of Fishes Subchronically Exposed to Cadmium Chloride and Copper Sulphate. Food Chemistry and Toxicology, 43:569574.

Cavas, T., and Ergene-Gözükara S. (2005). Micronucleus Test in Fish Cells: A Bioassay for In situ Monitoring of Genotoxic Pollution in the Marine Environment. Environmental Molecular Mutagen. 46:64-70.

Daoud, A.A., Nagpur, N.S., Sudhir, K.B., Ravindra, K., Kushwahaa, B. and Lakra, W.S., (2009). Assessment of Genotoxic and Mutagenic Effects of Chlorpyrifos in Freshwater Fish Channa punctatus (Bloch) Using Micronucleus Assay and 
Alkaline Single-cell Gel Electrophoresis. Food and Chemical Toxicology, 47: 650-656.

Dar, S.A., Yousuf, A.R., Balkhi, M.H., Ganai, F.A. and Bhat, F.A. (2015): Assessment of Endosulfan Induced Genotoxicity and Mutagenicity Manifested by Oxidative Stress Pathways in Freshwater Cyprinid Fish Crucian Carp (Carassius carassius). Chemosphere, 120, 273-283.

Dede, E.B. (1992). Effect of Lindane Pretreatment on Diclovors Toxicity in vitro and in vivo. Ph.D Thesis. Ahmadu Bello University, Zaria, Nigeria.

De Silva, P. M. C.S. and Samayawardhena, L. A. (2002). Low concentrations of lorsban in water result in far reaching behavioral and histological effects in early life stages in guppy, Ecotoxicology and Environmental Safety, 53, 248254.

Devi, Y. and Mishra, A. (2013). Study of behavioural and morphological anomalies of fry fish of freshwater teleost, Channa punctatus under chlorpyrifos intoxication, International Journal of Pharma and Bio Sciences, 4(1B), 865-874.

Ekué, M .R. M., Sinsin, B., Eyog-Matig, O. and Finkeldey, R. (2010). Uses, Traditional Management, Perception of Variation and Preferences in Ackee (Blighia sapida, K.D. Koenig) Fruit Traits in Benin: Implications for Domestication and Conservation. Journal of Ethnobiology and Ethnomedicine, 6(12), 1-14.

Elezaby, M.M., El-Serafy, S., Heckmann, R.K., Sharf, E., and Seddek M.M. (2001). Effects of Some Toxicants on the Freshwater Fish, Oreochromis niloticus. Journal of Egyptian and German Society of Zoology. 36:407-434.

Elif, I. C. and Erhan, U. (2006). Sub-lethal Effects of Commercial Deltamethrin on the Structure of the Gill, Liver and Gut Tissues of Mosquitofish, Gambusia affinis: A Microscopic Study. Environmental Toxicology and Pharmacology 2, 246-253.

Emmanuel, C.O., Helmina O.A., and Egwim C.E. (2014). Phytochemical Constituents of Seeds of Ripe and Unripe Blighia Sapida (K. Koenig) and Phytochemical Properties of the Seed Oil. International Journal of Pharmaceutical Science Invention. Vol.3, 9, PP. 31-40.

Ensminger, M., Bergin R., Spurlock F., and Goh, K.S. (2011). Pesticide Concentrations in Water and Sediment and Associated Invertebrate Toxicity in Del Puerto and Orestimba Creeks, California, 2007-2008. Environmental Monitoring and Assessment.

EPA (2001). Pesticide IndustrySales and Usages: 1996 and 1997 Market Estimates. www.epa.gov/Obeas1/pestsales/97pestsales/table1.html.

Fulton, M.H. and Key, P.B. (2001). Acetylcholinesterase Inhibition in Estuarine Fish and Invertebrates as an Indicator of Organophosphorus Insecticide Exposure and Effects. Environmental Toxicology and Chemistry, 20: 37-45.

Garcia, C. Z and Martinez, C. B. R. (2012). Biochemical and genetic alterations in the freshwater neotropical fish Prochilodus lineatusafter acute exposure to Microcystis aeruginosa. Neotropical ichthyology. vol.10 no.3:613-622

Giesy, J.P., Solomon, K.R., Coates, J.R., Dixon, K.R., Giddings, J.M. and Kenaga, E.E. (1999). Chlorpyrifos: Ecological Risk Assessment in North American Aquatic Environments. Rev Environmental Contamination Toxicology, 60:1-129.

Hartwell LH, Hood L, Goldberg ML, Reynolds AE, Silver LM, and Veres, R.C. (2000). Genetics: From Genes to Genomes. McGraw Hill Higher Education. ISBN 0-07-540923-2. pp. 70-98

Hellar, H. (2002). Pesticides Residues in Sugarcane Plantations and Environs after Long Term Use; the Case of TPC Ltd, Kilimanjaro Region, Tanzania.

Humphrey, C.A., Klump, D.W., and Raethke, N. (2004). Ambon Dansel (Pomancentrus amboinensis) as a Bioindicator Organism for the Great Barrier Reef: Responses to Chlorpyrifos. Bulletin of Environmental Contamination and Toxicology. 72, pp 888-895.

John, P.J. (2007). Alteration of Certain Blood Parameters of Freshwater Teleost Mystus Vittatus after Chronic Exposure to Metasystox and Sevin. Fish Physiology and Biochemistry, 33:15-20.

Kamal, K. S. and Renu, C. (2010). Study of Chromosomal Abnormalities in Channa punctatus Exposed to
Fenvalerate. Journal of Applied and Natural Science 2 (1): 70-73.

Mohanty, G., Mohanty, J., Nayak, A.K., Mohanty, S. and Dutta, S.K. (2011). Application of Comet Assay in the Study of DNA Damage and Recovery in Rohu (Labeo rohita) Fingerlings after an Exposure to Phorate, an Organophosphate Pesticide. Ecotoxicology, 20, 283-292.

Myers, M.S., Olson, O.P., Johnson, L.L., Stehr, C.S., Homt, R., and Varansi, U. (1992). Hepatic Neoplasm and Related Lesions and Exposure to Toxic Chemicals in Marine Fish from U.S West. Environmental Health Perspective, 90:7-15.

Nagpure, N.S. and Barat, A. (1997). A Simplified Method of Fish Chromosome Preparation by In Vitro colchicine Treatment. Indian Journal of Experimental Biology, 35:915-916.

Nwani C.D., NjokuIvoke, D.O., Ugwu C.A., Onyishi, G.C., Chinedu, P. E. and Ogbonna, S.A. (2013a). Investigation on Acute Toxicity and Behavioral Changes in a Freshwater African Catfish, C. gariepinus (Burchell, 1822) Exposed to Organophosphorous Pesticide, Termifos®. Pakistani Journal of Zoology, vol. 45(4), pp. 959-965.

Nwani, C.D., Ugwu D.O., Okeke, O.C., Onyishi, G.C., Ekeh, F.N., Atama, C, and Eneje, L.O. (2013b). Toxicity of the Clorpyrifos-based Pesticide Termifos: Effects on Behaviour and Biochemical and Haematological Parameters of African catfish Clarias gariepinus. African Journal of Aquatic Science.

Nwani, .CD., Lakra, W.S., Nagpure, N.S., Kumar, R., Kushwaha, B., and Srivastava, S.K. (2010a). Mutagenic and Genotoxic Effects of Carbosulphan in Freshwater Fish Channa punctatus (Bloch) Using Micronucleus Assay and Alkaline Single-Cell Gel Electrophoresis. Food and Chemical Toxicology, 48:202-208.

Nwani, C.D, Nagpure, N.S., Kumar, R, Kushwaha, B., Kumar, P., and Lakra, W.S. (2010b). Lethal Concentration and Toxicity Stress of Carbosulfan, Glyphosate and Atrazine to Freshwater Air Breathing Fish Channa punctatus (Bloch). International Aquatic Research, 2: 105-111.

Okwu, D.E. (2004). Phytochemicals and Vitamin Content of Indigenous Species of South-eastern Nigeria. Journal of Sustain Agriculture Environment, 6: 30-34.

Okwu, D.E. (2005). Phytochemicals, Vitamins and Mineral contents of Two Nigerian Medicinal Plants. International Journal of molecular medicinal and advanced science, 1(4): 375-381.

Osman, A.G., Abd El Reheema, A.M., Moustafa, M.A., Mahmoud, U.M., Abuel-Fadl, K.Y. and Kloas, W. (2011). In Situ Evaluation of the Genotoxic Potential of the River Nile: Micronucleus and Nuclear Lesion Tests of Erythrocytes of Oreochromis niloticus (Linnaeus, 1758) and C. gariepinus (Burchell, 1822). Toxicological and Environmental Chemistry, 93, 1002-1017.

Pan, G. and Dutta, H.M. (1998). The Inhibition of Brain Acetylcholinesterase Activity of Juvenile Largemouth Bass, Micropterus salmoides by Sub-letha Concentrations of Diazinon. Env. Res. Sec A, 79:133-137.

Piemental, D. and Levitan L. (1986). Pesticides- Amounts Applied and Amounts Reaching Pests. Biosciences, 36:86-91.

Ramesh, H. and Muniswamy, D. (2009). Behavioural Responses of the Freshwater Fish, Cyprinus carpio (Linnaeus) Following Sublethal Exposure to Chlorpyrifos; Turkish Journal of Fisheries and Aquatic Sciences 9: 233-238.

Rao, J.V., Begum, G., Pallela, R., Usman, P.K., and Rao, R.N. (2003). Changes in Behavior and Brain Acetylcholinesterase Activity in Mosquito Fish, Gambusia affinis in Rresponse to the Sub-lethal Exposure to Organophosphate Pesticide. International Journal of Environmental Research and Public Health, 2:478-83.

Rao, J.V. (2008). Brain Acetylcholinesterase Activity as a Potential Biomarker for the Aphida Assessment of Organophosphate Pesticide Toxicity in a Euryhaline Fish, Oreochromis mosambicus. Environmental Journal of Bioindicators, 3: $11-22$.

Rishi, K.K. and Grewal, S. (1995). Chromosome Aberration Test For The Insecticide, Dichlorvos, of Fish Chromosomes. Mutation Research, 344: 1-4.

Rishi, K.K. and Sunita G. (1993). Cytogenetic Screening of Effect of a Mosquito Larvicide on Kidney Cell Chromosomes of Channa punctatus, Abstr in Eighth India Congress of Cytology and Genetics, pp 87. 
Rishi, K.K., and Haobam, M.S. (1990). A Chromosomal Study on Four Species of Snake Heads (Ophicoephalidae, Pisces) With Comments on Their Karyotype Evolution. Caryologia, 43: $163-163$.

Rishi, K.K. (1989). Current Status of Fish Cytogenetics. Fish Genetics in India (Das and Jhingran, Eds) Hindasia, New Delhi, pp $1-20$.

Siang, H.Y. Yee, L.M. and Seng, C.T. (2007). Acute toxicity of Organochlorine Insecticide Endosulfan and Its Effect on Behaviour and Some Hematological Parameters of Asian Swamp Eel (Monopterus albus). Pesticide Biochemistry and Physiology, 89: 46-53.

Somdare, P.O., Nwani, C.D., Nwadinigwe, A.O., Nwani, J.C., Odo, G.E.,Ugbor, O.N., Ukonze, J.A. and Ezeibe, A.B.C.(2015). Fenthion Induced Toxicity and Histopathological Changes in Gill Tissue of Freshwater African Catfish, C. gariepinus (Burchell, 1822). African Journal of Biotechnology, vol. 14(25), pp. 2103-2113.

Sunmonu, T.O., and Oloyede, O.B.(2006). Changes in Liver Enzyme Activities in African Catfish (Clarias gariepinus) Exposed to Crude Oil. Asian Fisheries Science. 19: 104-109.

Sunanda, M. Rao C. S. J., Neelima, P. Rao, G. K. and Simhachalam, G. (2016). Effects of Chlorpyrifos (an Organophosphate Pesticide) in Fish. Int. J. Pharm. Sci. Rev. Res., 39(1), 299305

Testai, E., Buratti, F.M., and Consiglio, E.D. (2010). Chlorpyrifos. In: Krieger, R.I., Doull J, van Hemmen, J.J., Hodgson, E., Maibach, H.I., Ritter, L., Ross, J., Slikker, W. (eds) Handbook of Pesticide Toxicology, vol 2. Elsevier, Burlington, MA, pp 1505-1526.

Timchalk, C. (2010). Organophosphorus Insecticide Pharmacokinetics. In: Krieger, R.I., Doull J, van Hemmen, J.J., Hodgson, E.,
Maibach, H.I., Ritter, L., Ross, J., Slikker, W. (eds) Handbook of Pesticide Toxicology, vol 2. Elsevier, Burlington, MA, pp 1409-1433.

Toni, P. G. and Lília, M. M. (2009). Evaluation of Genotoxicity Using the Micronucleus Assay and Nuclear Abnormalities in the Rropical Sea Fish Bathygobius soporator (Valenciennes, 1837) (Teleostei, Gobiidae). Genetics and Molecular Biology, 32: 394-398.

Topal A. Atamanalp M. Oruç E. Demir Y. Beydemir Ş. and Işık A. (2014). In vivo changes in carbonic anhydrase activity and histopathology of gill and liver tissues after acute exposure to chlorpyrifos in rainbow trout, Arh Hig Rada Toksikol, 65, 377-385.

Veronica, M. Dosso., Jacob K. A., Sussana, C., and Sarah, A. (2014). Ackee (Blighia sapida) fruit arils: Nutritional, Phytochemicals and Antioxidant Properties. International Journal of Nutrition and Food Sciences, 3(6): 534537.Veterinarni Medicina, 59, 2014 (9): 433-439.

Vocke, G. (1986). The Green Revolution for Wheat in Developing Countries, US Department of Agriculture, USA.

Werimo, K. Bergwerff, A.A. and Seinen, W. (2009). Residue Levels of Organochlorines and Organophosphates in Water, Fish and Sediments from Lake Victoria-Kenyan Portion. Aq. Eco.Health Man., 12:337-4341.

Whitney, K.D., Seidler, F.J., and Slotkin, T.A. (1995). Developmental Neurotoxicity of Chlorpyrifos: Cellular Mechanisms. Toxicology and Applied Pharmacology, 134: 53-62.

Yadav K. K. and Trivedi, S. P. (2009). Chromosomal Chromosomal Aberrations in a Fish, Channa punctata After In vivo Exposure to Three Heavy Metals. Mutation Research, 678:7-12. 